\title{
Musrena and E-Musrenbang Dictionary-Based Development Planning Against Gender Perspective Policy
}

Masrizal

Departement of Sociology, Faculty of Social and Political Sciences, Syiah Kuala University in Banda Aceh, Indonesia

masrizalfisip@unsyiah.ac.id

\begin{abstract}
This paper describes how the area of women's participation through Musrena (consensus of action female plan) mobilized by a group of women at the grassroots is called the organization of women's centers (Balee Inong) in Banda Aceh, which up to now there are 18 (eighteen) Balee Inong on 90 village. Stage of this study describes the field findings of development planning based e-Musrenbang dictionaries through the concept of gender framework which Participatory Rural Appraisal (PRA) perspective approach, with data collection techniques using literature review, observation, interviews and Focus Group Discussion (FGD). The results show that in the application of e-Musrenbang, there is a proposal dictionary containing the types of activities on SKPD program that already has a unit price, so that the operators of gampong select and insert the required volume. The application also comes with WebGIS which is connected with webGIS Bappeda so the village has the option of choosing a location that became the object of the proposed development they propose. Each village was given limit budget of pagu by PIK (Indicative Pagu Sub-District) which is one-of the policy of the Government of Banda Aceh in the proportional budget for the district level and village, that in 2015, Musrena was directed at explanation readiness of Balee Inong group in connected with related SKPD which each gampong gets indicative pagu $10 \%$ of 200 Million per village of budgeting data through sources of funding APBK Banda Aceh, so that citizens can access and understand it online to their village where the proposal can be accepted by the relevant SKPD.
\end{abstract}

Keywords: Development, E-musrenbang, Gender, Musrena, Policy

\section{INTRODUCTION}

System development planning and public aspirations have been carried out through Deliberation and planning (MUSRENBANG) which starts from gampong (village) and district/city level. The implementation of the lowest unit at the village level is still running top-down. Mechanism of representative of the community is usually more represented by the chairman or members of Tuha Peut. So, it seems more of a venue for socialization in the community at time synchronization the work plan between Aceh Government Unit (SKPA) and Government Unit District/City (SKPK). In addition, in terms of execution time is often criticized too short so that people have less opportunity to criticize and clarify their proposal, other than that some people also often come with do not prepare so they do not master the substance of the proposed programs. Technically, the implementation of Musrenbang still has done marathons and parallel. Starting
I.

from the village level had prepared a schedule made by BAPPEDA in Banda Aceh. In one day, it was divided village in two sections; in the morning and the afternoon. Each village held a consultation in meunasah or village halls office within 3-4 hours. If we observe the flow of the planning area, while MUSRENBANG becomes one of the activities that must be passed, it is clear that the planning is patterned technocratic-formalistic in order to capture their aspirations administrative.

The result formulation is more physical development such as the construction of the fence, village offices, repair of roads and construction of conference hall. Formulation of proposals has been formalized in the form that has been spread by Bappeda. Because MUSRENBANG is a tiered forum, the proposals submitted at the village level will continue to be brought to a higher level. So that is where the problem often appears. For example, the first issue, all programs that have been agreed at the under level (the Village/ Gampong) are not necessarily accommodated 
PRESS was delivered to the forum at subdistrict level to district/city. So, many proposals did not take a look at the needs of each level village, on the contrary, the proposal should have been submitted in previous years become a priority again, often being repetition of the previous year's proposals. The second issue, the low involvement/participation of women in it, thus directly or indirectly, many programs and policies that were implemented by the government of districts/cities often problematic related to gender sensitivity. Therefore, if it was seen from the implementation mechanism, the rate of women's presence is minimal, the formulation of programs that was produced is inequitable of gender, so it is necessary the establishment of a similar organization that can accommodate all the problems and needs of women, so it is necessary to hold MUSRENA.

Generally, MUSRENA aims to create the scheming of Banda Aceh with Gender Justice based by adapting the planning system of bottom up and top down. While specifically are: (1) As a means of direct communication for women in the area at the same time as a learning process to formulate an action plan development. On the other hand, a learning center for women to participate actively in addressing the problems and needs significantly in MUSRENBANG activities. (2) As one of the basic considerations proportions Budget Gampong (APBG or Gampong Aid). (3) As a special effort while the city government to ensure women's participation in the planning, implementation, monitoring and enjoy the fruits of development.

General benefit of MUSRENA is to strengthen the capacity of women in the development planning process, and to provide input to the government on the aspirations of women, listen more clearly the things the aspirations of women, and then can be integrated in the work program of government. While the special benefit is the Government of Banda Aceh can know the complaints, problems and needs of women so that they can be formulated the solution of prevention in development planning. Under government of Alm. Mawardi Nurdin and Illiza Sa'aduddin Djamal, Musrena (deliberation female action plan) which is run by the mayor Regulation (Perwal No 52 of 2009), and has received national awards in the major of women's participation in development. Furthermore, now the head of district has formed the Women's Organization that called Balee Inong which the decree by the office of Women's Empowerment and Family Planning (AEOS). Balee Inong is a collection of individual women who are working together in resolving the problems of development, both from the village level up to the level of the sub-district and district/city. This organization only exists in
Banda Aceh, and it cannot find in other region outside the city of Banda Aceh. Now, the number of BI organization is 18.As known in 2015, BAPPEDA Banda Aceh has designed e-Musrenbang dictionary which pagu indicative of budgeting 200 million rupiah for each gampong, which is $10 \%$ destined for Balee Inong's activities in 90 villages and $90 \%$ other for gampong's activities that managed by gampong officials. So far, the organization BI is in Kemukiman level, so as a organization that gets serious attention of the Government of Banda Aceh, the crucial knowledge of how to design a program of activities that support the achievement of the MDGs. To achieve it, the authors want to see their strengths and weaknesses as practiced by the organization Balee inong in participation through Musrena as an affirmative Musrenbang are not bias of the needs of women. Kusmawati Hatta et al: 2012, Explaining that the involvement of Women in Development is not maximized, it is based on the research findings on the use Musrena in enhancing the capacity of women is still not fully become a top priority. This research uses the theory of Women with qualitative research methods with data collection techniques, observation, interviews and focus group discussions.

The findings of the research explained that: first, although the mayor about Musrena regulations have been made but not yet fully these regulations serve as a legal force in running the empowerment of women in development. Secondly, most women have not made Musrena as a place to express their aspirations, this is evidenced by the number of attendance is still below the average expected by the City. The third has not been good relations between the elite women at the level of the village with the village so many programs have not been responsive to women, although women in the village have formed an organization Balee Inong or PKK. Lastly, control of the city government on the implementation of the work program resulting from Musrena still not up so that it becomes one of the main reasons why women have not fully got a room in the building.

Based on the background described above, the problems can be taken in this study include:

1. How does the effect of Musrena implementation toward the government's development policy in Banda Aceh?

2. How long Musrena becomes a mediaaspirations of women in development?

3. Who are the actors that influence the implementation of Musrena in Banda Aceh as an affirmative Musrena? 
focus point are:

1. To investigate and to analyze the effect of Musrena implementation toward development policy of government in Banda Aceh

2. To know how long Musrena becomes a mediaaspirations of women in development

3. To investigate the actors who influence the implementation of Musrena in Banda Aceh as an affirmative Musrenbang

\section{MATERIALS AND METHODS}

This research uses a type of field research with qualitative methods. The technique of data collection observations, in-depth interviews, focus group discussions and study the documentation. This pattern is used to answer the pattern of women in the village level participate in the development of through Musrena forum (Consultation action plan for women) as a place of conveying aspirations in answering the problems faced by women to realize that gender equitable development in the city of Banda Aceh. In addition to the year 2009 city of Banda Aceh has become one of the city that has been legalize these local regulations about gender-friendly.

\section{Theoritical Framework}

In this study, the authors will describe some patterns of gender theory analysis framework developed by some experts which were used to see the model of implementation the concept of Musrena through women organizations power on the grassroots level called women's centers in the city of Banda Aceh, they are:

1. Harvard Framework(Candida March et.all: 1999)

Harvard gender analysis framework is more concerned in making the gender division of labor, role in making decisions, the control level of visible resources. Three main sets of data are required: Who does what, when, where, and how much the allocation of time it takes? This is known as "Activity Profile".Who has access and control (such as policy-making) of a particular resource? It is often known as "Profile Access and Control" Who has access to and control the "benefits" such as food production, money and so on. Factors affecting differences in genderbased division of labor, as well as access and control that exist in "activity profile" and "Access and control profile".
The purposes of this analysis tool are:

- Discussing the allocation of economic resources for men and women

- Assist project planners to more efficiently and increase overall productivity

Strength/virtue of Harvard Framework:

- Practical and easy to use, especially at the micro-level analysis of community and family

- Useful for detailed baseline information

- $\quad$ Focus on visible things, objective fact, focus on gender differences and not on gaps

- Easy communicated to the beginner / layman

Limitations:

- There is no focus on the dynamics of power relation and inequality

- $\quad$ Not effective for intangible resources such as social networks and social capital

- Too simplify complex gender relations, lost aspects of negotiation, bargaining, and the division of roles.

In this theory, it is developed how a group of women (Balee Inong) who have had access budgeting in order to be able to control the implementation of programs that have been planned in Musrena, so that the work program which has been stated is not just planning, but also into e-budgeting that have been programmed through E-Musrenbang, beside the strength of leadership in favor the women needs.

2. Framework Moser or the Gender Roles Framework. Briefly, this framework offers a distinction between practical needs and strategic in planning the community empowerment and also focus on women's workload. Interestingly, it does not focus on a particular organization but more focused on the housewife. The three main concepts of this framework are: first, thetriple roles of women at three levels: the reproductive work, productive work and community work. This is useful for mapping the gender division of labor and allocation of work. Second, Attempting to distinguish between practical needs and strategic for women and men. Strategic needs relate to the need for transformation of the status and position of women (such as subordination). While the third, policy analysis approach - focus on welfare, equity, antipoverty, efficiency and empowerment (Moser: 1993).

Strength / The virtue of Moser Framework:

- Being able to see the disparity of women and men 
${ }^{\text {PRESS }}$ The emphasis on all aspects of the work in which to make the women multitasking are seen.

- Emphasizing and questioning the assumptions behind project-2 intervention

- Emphasis on the differences between to fulfill Practical-basic needs and strategic needs

Limitations/Weaknesses of Moser Framework:

- Focus on women and men and not on social relations

- Does not emphasizes other aspects of inequality such as access to resources

- If asked, the women will identify practical needs. Finding the size- 2 hard strategic needs. Strategic change is a process that is complex and contradictory. In practice, something practical and strategic closely related.

- Different policy approaches-2 mixed in practice

- Work effectively has function as an analytical tool rather than planning intervention.

In the study of this theory encouraged the women's organization that grew out of a community of housewife, based a married woman to look at opportunities that fit in developing what is becoming strategic and practical needs, as well as point the emphasis is on the stage of advocacy or intervention projects have been launched each year which began in 2007 to the present, through a formal forum that was designed by the Regional Planning Agency (Bappeda) Banda Aceh, called Musrena. Besides, it was given the independence for this organization to access the APBK (Budget Expenditure district/city), through the channel village funding, where women representatives of each village to plan its work program for the regions along the village officials planned work program in support of the women's needs. This theoretical approach deserves to be as a "scalpel" in running or analyzing how far women's groups were not involved in problem-solving efforts for village development.

\section{The Concept of Web Geographic Information} System ( WebGIS )

According to Prahasta (2007), Web GIS is the application of GIS (geografic information system) or digital mapping are utilizing the Internet as a communication medium that serves to distribute, publish, integrate, communicate and provide information in the form of text, digital maps then perform the functions of analysis and queries related to GIS through the Internet. Meanwhile, according to Setiawan and Rabbasa, the use of spatial data is necessary for various purposes such as research, development and regional planning, and the management of natural resources. Spatial data users endure the lack of information about the existence and availability of spatial data that is needed. The dissemination of spatial data that has been done using existing media covering the print media (map), CD-ROMs and other storage media perceived lack sufficient user needs. Users are required to come and see the data in the place (data provider). This reduces the mobility and speed in obtaining information about the data. Hence, it is needed the Web GIS.Mapping in the web application architecture is divided into two approaches as follows:

\section{a)Thin Server Approach}

This approach focuses on the server side. Almost all processes and data analysis were done by the server side request. Data processing results are sent to the client in a standard format.

\section{b) Thick Client Approach}

On this approach, the client side data processing is done using several technologies. In general, the development and implementation of WebGIS will support the dissemination of spatial data. So that people will be able to have access to the data and results of GIS analysis. Form of WebGISapproach provide an opportunity for the Women's organization at the level of the grassroots to understand the working system of government to accommodate any work programs that have been proposed in the forum of Musrena and can freely oversee the implementation of the proposed work program, and opens the door of communication with relevant government that expert on the development planning proposal which is planned and reduce the fraud in determining the prioritization of the proposed work program of Musrenbang or Musrena.

\section{RESULT OF RESEARCH AND DISCUSSION}

In studying the participation of women who are members of the organization Balee Inong through Musrena forum, the approach used is a qualitative method of data collection techniques: observation, interview and FGD (focus group discussion), and also the literature study. The author elaborates as follows the findings by using analytical tools approach refers to gender theory that has been presented in the previous chapter that detailing how grassroots organizations incorporated into Balee Inong Banda Aceh understand the strategy of development efforts in gender perspective. 


\section{ena as a Afirmative Musrenbang}

Leave on the question of formalism MUSRENBANG with various problems, then there is an idea of the deputy mayor of Banda Aceh at the time, and now become the Mayor for replacing Alm. Mawardi Nurdin, to establish a media that can accommodate the aspirations of women in city development planning, namely MUSRENA. This forum was established by the government of Banda Aceh, on three main initiators Vice Mayorelected, Illiza Sa'aduddin Djamal; Fahmiwati and Suzan of GTZ-SLGSR, which in the initial implementation is also supported by various academics and other women activists such as Soraya Kamaruzzaman, Badrunnisa, Kusmawati Hatta, Ria Fitir, Tasmiati as a facilitator. Then Bappeda Banda Aceh became a leading sector in running the Musrena, by dividing the territory into three regional: that started since 2007, which preceded facilitator by Kusmawati Hatta, Ridwan Ibrahim, Badrunnisa, and the last in 2015 was facilitated by Maisarah and Masrizal, from academia and women activist.

Generlly, MUSRENA aims to create the planning of Banda Aceh in Gender Justice Based by adapting the planning system of bottom up and top down. While specifically are: (1) As a media of direct communication for women in the district at the same time learning to formulate an action plan development. On the other hand, it becomes learning center for women to participate actively in addressing the problems and needs significantly in MUSRENBANG activities. (2) As one of the basic considerations proportions of Budget Gampong (APBG or Gampong). (3) As a special effort while the city government to ensure women's participation in the planning, implementing, monitoring and enjoying the fruits of development.

General Benefits of MUSRENA are to strengthen the capacity of women in the development planning process, and to provide the suggestion to the government on the aspirations of women, listen more clearly the things the aspirations of women, and then can be integrated in the work program of government. While the special benefit is the Government of Banda Aceh can learn the complaints, problems and needs of women so that they can be formulated the solutions in development planning.

The reality of implementation of Musrena when referring to the theory what the author developed above that almost all the concepts in a gender perspective is used as a scalpel in developing Musrena. The power of the women's group Banda Aceh shows the public that there has been a shift in the pattern of development, where previous power of patriarchy toward Musrenbang shifts that will begin to see in the needs of women in development. It is also inseparable from the important role of the mayor who understands the needs of women and supported by the institutions of civil society movements and the willingness of a group of men to accept the need to change the way of development. If refers to the Acehnese women's movement in the past, where Aceh also has spawned a lot of women who understand the strategy of a war policy based on the customs and understand the importance of women plunged into the world public in voicing their aspirations. They are Tjutnyak Dhien, Tjoet Meutia, Meurah Intan, Sultanah Safiatuddin, and other Acehnese heroine. Now the movement has begun to go up again in realizing the ideals of development, many analysts say the movement is started again when the tsunami hit Aceh in 2004, where almost all the civil society movement came to provide assistance both morally and materially. No exception for NGOs concerned with the empowerment of women public area, such as UN-Woman, GTZSLGSR, and various other names that contributed to Aceh Bangkit.

The apparent of the women's organizations after the tsunami is the forerunners of the strength of women's organizations in Aceh in claim the rights, various events Aceh many women leaders have voiced their aspirations through a character that is fully committed to fight for the fate of women who have long been curbed by the power of patriarchy culture. In the city of Banda Aceh, the capital of the Province begin the apparent of women's centers movement, nearly 9 districts are represented at the grass-roots organization, which until now the number is already 18 organizations, the number of women recruited from 90 village in Banda Aceh. Other force in Banda Aceh is the full force of the city government who is also the initiator the birth of the organization. In beginning, city government has an institute named Woman Development Center (WDC). For others district/city, the institute is named P2TP2A, as a connector of the government in providing information and efforts to solve the problems faced by women, both for empowerment and handling of cases faced by women. But in 2013, WDC is no longer fully engaged in the handling of the case, but specifically in the field of empowerment of women, for the year head of the PP and KB Banda Aceh to form a new P2TP2A, due to specific needs. Referring the histories, WDC institution born of a joint agreement between the women belonging to the other women's NGOs such as Balai Shura, KKTGA, Flower, MISPI, Annisa Center and several other women's NGOs. Then they have a goal of how women Banda Aceh are quickly recovered from the trauma of the tsunami and independent in meeting their needs. 


\section{LEGAL BASIS OF MUSRENA}

To strengthen its existences from legalformal side, then it was appeared a number of regulations in local level, those are:

- Perwal MUSRENA, No. 52 year 2009

- QANUN Justice of Gender City;

- Woman position who place strategic in government;

- RPJM (2007-2012);

- Renstra, Renja, KUA/PPAS.

Whereas national regulations relied upon and also to keep sustainable particularly with respect to the barriers administrative regulation refers to participatory development, primarily:

- UU RI No. 25 Th. 2004 (UU 25/2004) about National Development Planning System (SPPN);

- UU RI No. 32 Th. 2004 about Local Government, and;

- UU RI No. 33 Th. 2004 about Finance Balancing Between Central Government and Regional Government;

- UU RI No. 7 Th. 1984 about Legalization of Convention of elimination all of discrimination toward women (Lembaran Negara Tahun 1984 Nomor 29 Tambahan Lembaran Negara 3277);

- UU RI No 39 year 1999 about Human Right;

- UU RI No. 25 year 2000 about Propenas especially Chapter VIII about position and quality of women life;

- UU RI No. 11 year 2006 about Aceh Government, especially in: Ps. 75 about represented of women and local political party ,Ps. 138 about women and establishment of MPU,Ps. 154 about women and economics matter, ps. 215 about women and education,ps. 23l about women and children and Human .PS 226 about women and health and psycosocial; Instruction of President RI No. 9 Year. 2000 about Gender Mainstreaming In national Development;

- PP No. 19 Th. 2001 about Gender mainstreaming;

Circular Letter of State Minister For National Development Planning/the Head of Bappenas and Minister for Internal Affairs No.0008/M. PPN/01/2007 and 050/264A/SJ about Technical Guideline of MUSRENBANG Implementation in 2007. SEB is a transition rules while waiting of Government Rules (PP) as the rule of implementation UU SPPN;

- Convention on the Political Rights of Women, New York 31 March 1953,
Indonesian ratify the convention on 16 December 1998);

- Obtional Protocol to Convention of Elimination all of discrimination to women;

- PP No. 8 Year 2008 about stages and ways of arranging, controlling, evaluating of regional development.

\section{The Advantages of e-Musrenbang Dictionary for Banda Aceh Society.}

The advantage of e-Musrenbang dictionary application is the public can follow up how far their development program that has been proposed to be accommodated by the Government of Banda Aceh, through SKPD (local government unit) related. In this application, there is a proposal dictionary contains types of programs on education activities which already has a unit price, so that operators select and enter the village the required volume. The application also comes with WebGIS is connected with webGIS Bappeda.So the village has the option of choosing a location that became the object of the proposed development they propose. "Each village was given limit budget by PIK (Indicative Pagu Sub-District) which is one of policy by Pemko Banda Aceh in the proportional budget for the district level and village. With the presence of this application, the expected quality of planning involving the public directly can be done well, so that the goal of Banda Aceh being a Cyber City will be realized soon.

Another point of this study, we can refer to the concept of empowerment developed through Participatory Rural Appraisal (PRA), or the study of empowerment developed by Longwe directly focused on the creation of a situation/conditioning where imbalances, discrimination and subordination were resolved. Longwe create the way to reach the level of empowerment and equality which indicated that the fulfillment of basic needs-practical woman is never equal to, empowerment and equal. Decision-making (control) is the culmination of empowerment and equality. Musrenbang as an annual event mandated by the law is an event of the meeting of the village residents to discuss their problems and decide short-term development priorities. Musrenbang is a form of public participation in the development of bottom-up approach to ensure the development in accordance with the needs. In order to socialize the new system online Musrenbang, Bappeda invited the district and geuchik/head of village in the region of Banda Aceh to introduce electronic applications of Musrenbang.

Later in 2015, a group of women who are members of the organization Balee Inong gained 
PRESS Ige about the operational system of eMusrenbang because from the Indicative Pagu of Gampong in Banda Aceh, $10 \%$ of the village's budget is managed by women's groups, where for example in budget 2016, $10 \%$ of total budget of 200 Million Pergampong / village is reserved for program which relating to women. In Banda Aceh, there are 90 Gampong so there are about 1.8 billion rupiah will be managed by a group of women who are members of the organization Balee Inong. During this time the organization Balee Inong was accompanied by Women Empowerment and Family Planning and Women's Development Centre in Banda Aceh.

\section{Realization Development perspective

$\begin{array}{ccc}\text { of } & \text { Musrena } & \text { toward } \\ \text { policy } & \text { which } & \text { Gender }\end{array}$

After Musrena as a forum for women's aspirations of Banda Aceh in terms of development, has many perceived benefits, both from the economic, education, cultural, religious, political and other social sectors. It also with the relevant institutions, a program of activities which realized more directed to the needs of society, not just a program without having the full support of the society, especially women's groups as the object of aid beneficiaries.

Since Musrena was realized in 2007, a program that leads to the importance of women realized gradually and no longer see the importance that are implemented to importance which are temporary, only for women but lead to the interests of gender (male and female). For example; in the forum, there is the proposal which is realized as, additional working capital revolving fund, street lamp lighting in the village, tajhiz mayit training, and other social programs. Subsequently in 2015, the indicative pagu of village is reserved for women $10 \%$ of APBK. So, many of the proposed program helps the urban development in line with vision and mission of Banda Aceh from 2007-2012, until 2012-2017. However, the passage of program activities initiated by women's groups is inseparable from the attitude of the leadership's viewpoint by Illiza Sa'aduddin Djamal, as a woman who was born of a political party cadres, and also the organization of Women in the city of Banda Aceh, both at the level of village organizations (Balee Inong), also NGOs at the city level, such as the WDC, KKTGA, Flower, RPUK, An-nisa Centre, MISPI, Balai Syura, LBH, and other NGOs which is located in the capital of Aceh Province. Furthermore, the Role and Function of Civil Society Organizations in Banda Aceh, in Musrenbang and Musrena can be explained:
(1) The development of strategic coalitions and effective network to influence decision making in the planning and budgeting process in the region to implement participatory budgeting; (2) Besides as a participant, they also act as facilitators for Musrenbang; (3) Provide advocacy, training, mentoring, research, and budget analysis. (4) Provide and improve public access to planning and budgeting information so that they are more concerned and actively contribute to the process. (5) Creating a public forum to encourage discussion of budget before the budget is approved and ratified; (6) Conducting a campaign to encourage budget transparency; (7) Monitoring and evaluating the budget and the performance of public services; (8) Help DPRK to conduct a review (review) and an assessment of the impact of the budget proposed by local governments, especially the budgetary impact on poverty alleviation and the implementation of minimum service standards. (9) In collaboration with the printed and electronic media to ensure the goals of planning and budgeting participatory, process, and the results published..

Likewise, the role and function of Banda Aceh City is to strengthen the involvement of Parliament in Musrenbang and Musrena particular and all stages of the planning process. In addition, the time schedule recess of Parliament needs to be synchronized with the time schedule of Musrenbang and calendar planning and budgeting. Thus, the Parliament could contribute actively and effectively in Musrenbang during the activity undertaken. Where at the time Musrena is doing, DPRK listen to exposure to each group Women's organization of Banda Aceh who are members of Balee Inong, and a pressure point that most influence on realization of Musrena program is Legislators are elected from specified electoral district (constituency) must be present, and contribute to the forum. The role and function of the DPRK that is reinforced in Musrena forum as follows:

1. The active involvement of the Commission, the relevant committee of Parliament in the discussion, review, and evaluation of public proposals in Musrena and Musrenbang;

2. Understanding of the needs and aspirations voiced in Musrenbang and provide input on the priority programs based on community priorities;

3. The presence of consistency and balance between the program and the annual budget with the priority areas of national scale and among the sectoral priorities with budget allocations;

4. Musrenbang apply standards appropriate public consultation; 
needs to be included in the program plan on DPRK to support programs and activities that are prioritized in Musrena in the proposal Musrenbang. Gender budget advocacy applied since 2001 by some NGO, forum members of Gender Budget Analysis who work at the national level with a regional network and forum members who work in the area. At the national level, these forums do gender budget advocacy urging the People's Consultative Assembly (MPR) in order to allocate a budget of 30 percent for education, for health 15 percent, and women's empowerment budget 5 percent of the state budget (Decree No. 6 of 2002). For Banda Aceh, it was boosted by creating of Perwal Musrena No. 52 of 2009 which requires $5 \%$ of the budget allocation on SKPD directed at the realization of the gender program. Based on the various strengths of the law so that the activities Musrena in Banda Aceh running well and will be dismissed when Musrenbang already accommodate the full participation of women in development planning meeting, until the ninth year Musrena still has the shortcoming, so Musrena which is under the control of Bappeda Kota Banda Aceh continues to improve for the next Musrena improvement by establishing coordination with the relevant parties.

\section{CONCLUSION}

As a form of affirmative Musrenbang of government in order to increase the participation of women in development, the establishment of the Forum Musrena that has been conducted continuously for 9 years, since 2007 to 2015, in Banda Aceh, with the implementation mechanisms of networking information and activities program since the Pre Musrena designed from the village, until to districts level, until it was into Musrenbang realization in City level, until now continually enhanced in accordinance to the circumstances. The results of each year, there is also be integrated into the SKPK program although it did not increased significantly. Therefore, MUSRENA is still needed to be a media of learning for women in issuing aspiration and inspiration and help the planning of urban development that participatory gender in future.

In addition, the implementation of MUSRENA, already known and studied by various interested parties for the development, improvement and replication program to conduct participatory planning system. Even, the organizations WDC Banda Aceh in cooperation with the Government of Banda Aceh with funding from the Ford Foundation has conducted socialization program Musrena through workshops to others district/city in Aceh such as South Aceh, Aceh Singkil, Subulussalam, Pidie Jaya, Aceh Besar and Sabang. The results of socialization was found that almost all regencies/cities are making Musrena as obstruction good examples (best practice) in implementing the program gender-equitable areas respectively, with different name, there is called Team Vocal Point Gender or other names in accordance with the agreement of each region. And even the government of Banda Aceh with their Musrena has gained Innovation Government Awards from the Ministry in 2012.

\section{REFERENCES}

Abu Hurairah, 2006, Dinamika Kelompok (konsep dan Aplikasi), Refika Aditama, Bandung

Azhar Arsyad, 1996, Media Pembelajaran, Raja Grafindo Persada, Jakarta

Candida March, Ines Smyth, and Maitrayee Mukhopadhyay, 1999, A Guide to GenderAnalysis Frameworks, London: Oxfam Publishing.

Caroline O.N. 1993 Gender Planning and Development: Theory, Practice, and Training. London: Routledge.

Eddy Prahasta, 2007, Membangun Aplikasi WebBased GIS dengan MapServer, Informatika, Cetakan Pertama, Bandung

Kusmawati Hatta dkk, 2012, Modul Musrena, WDCFord Foundation- Pemko Kota Banda Aceh

Masrizal dkk, 2015, Modul Pemberdayaan Perempuan (Sebuah Analisa Balee Inong dan Relasi Sosial) WDC- Ford Foundation, Banda Aceh Moser,

Nasaruddin Umar dkk, 2003, Pemberdayaan Perempuan Melalui Pemahaman Agama, PSG IAIN Sunan Ampel Surabaya

Onny S. Prijono, 1996, Pemberdayaan Masyarakat (Konsep, Kebijakan dan Implementasi), CSIS, Jakarta

Puspitawati, 2012. Gender dan Keluarga: Konsep dan Realita di Indonesia. PT IPB Press. Bogor Trisakti, Handayani dan Sugiarti. 2001. Konsep dan teknik penelitian gender. Pusat Studi Wanita dan Kemasyarakatan UMM. Malang

http://www.bandaacehkota.go.id/berita965-

Dengan_e-

Musrenbang,_Masyarakat_Lebih_Terlibat_Dal am_Pembangunan.html\#.VeOpiyuUqKEhttp:/ /www.bappedabandaacehkota.go.id/strateg i/musrena.

http://kalyanamitra.or.id/eventsdetail.php?id=0\& iddata $=1$ 